\title{
Comparison of Conventional Concrete and Replacement of River Sand by Waste Foundry Sand and Cement by Nano-Silica
}

\author{
${ }^{1}$ SWATHI. S, ${ }^{2}$ DIVYALAKSHMI. E, ${ }^{3}$ ELAKKIYA. U, ${ }^{4}$ PREMALATHIKA. $R$ \\ ${ }^{1}$ Assistant Professor, ${ }^{2,3,4}$ Final year student, Civil Engineering, MRK Institute of Technology, \\ Kattumannarkoil, India.jedhani18@gmail.com, divyakeran123@gmail.com
}

\begin{abstract}
This paper presents an experimental investigation on the properties of concrete in which like cement is partially replacing by used nano silica and is partially replacing by used waste foundry sand. Because now a day the world wide consumption of sand as cement and as fine aggregate in concrete production is very high. Nano silica and waste foundry sand are major by product of casting industry and create land pollution. The cement will be replaced with nano silica and the river sand will be replaced with waste foundry sand $(0 \%, 5 \%, 10 \%, 15 \%, 20 \%)$. This experimental investigation was done and found out that with the increase in the nano silica and waste foundry sand ratio. Compression test has been done to find out the compressive strength of concrete at the age of $7,14,21$, and 28 . Test result indicates in increasing compressive strength of plain concrete by inclusion of nano silica as a partial replacement of cement and waste foundry sand as a partial replacement of fine aggregate.
\end{abstract}

Key words: Waste foundry sand, Nano- silica, Cement,River sand, Compressive strength.

\section{INTRODUCTION}

In foundry industry during the casting process a large amount of by-product material is produced. The metals which usually cast in foundry industry are cast iron, steel, aluminium, copper, brass and bronze. Over two third of the total by-product material consists of silica and the one third of the total by-product material consists of metals which is casted on the sand. In foundry industry they use high quality silica sand for moulding the metals and also for casting purpose.

To overcome the use of natural resources and use of waste material like foundry sand in concrete could be make possible to achieve the low cost construction.

The main objective of this experimental work is to compare the effect of foundry sand in OPC concrete with the conventional cement concrete and to see the effect of nano silica and foundry sand inclusion in OPC concrete. Also the study is summarize based on compressive strength of OPC replaced foundry sand with fine aggregate and replaced nano silica with cement.

Materials are used: Cement(OPC), FA, CA, Water, WFS, Nano silica.

\section{OBJECTIVE}

\footnotetext{
* To study the properties of the waste foundry sand.

* To overcome the disposal problem of industrial waste.
}

* To study the compressive strength of the specimens. This is replaced by WFS with river sand and nano silica with cement.

* To draw conclusion and give recommendations based on the research finding and indicate areas for further study.

\section{SCOPE}

* The mechanical strength of the concrete is enhanced in the partial replacement of WFS and Nano-silica.

* To reduce the construction cost.

\section{LITERATURE REVIEW}

Several authors have reported the use of waste foundry sand and nano silica in various civil engineering application.

khatib (2005) [9] studied the properties of concrete which contain fine recycled aggregate. The recycled aggregate consists of crushed concrete (CC) or crushed brick (CB) with particles size less than $5 \mathrm{~mm}$ in diameter. The fine aggregate in concrete was replaced with $0 \%, 25 \%, 50 \%$, and $100 \%$ CC or CB. Results said that concrete made with the replacement attains up to $50 \%$ CB shows the same 19 long term strength. Even at $100 \%$ replacement of fine aggregate of fine aggregate with $\mathrm{CB}$, the reduction in strength was only $10 \%$. After 28 days of curing, the amount of strength development in concrete containing is 
either $\mathrm{CC}$ or $\mathrm{CB}$ was higher than that of the conventional concrete. There are several types of waste materials/ by products, which can be used in concrete as a partial replacement of fine aggregate. Some of the materials which can be used are recycled fine aggregate, coal bottom ash, stone dust and glass cullet, sewage sludge ash, and waste foundry sand, ect...

Rakshvir and Barai (2006)[10] studied the various physical as well as mechanical properties of recycled concrete aggregates. Recycled concrete aggregates (RCA) are different from natural aggregates and concrete made from them had different physical as well as chemical properties. The percentage of RCA varie sand it was found out that the properties like compressive strength likely to decrease about $10 \%$ compared to the conventional concrete. Water absorption of RCA was found to be greater than natural aggregates.

Cachim (2009)[14] viewed that the workability of fresh concrete, compressive strength, tensile strength, modulus of elasticity and stress strain behaviour of hardened concrete. The replacement ratios of fine aggregates by $15 \%$ and $30 \%$ were prepared with a water/cement ratios of 0.45 and 0.5 . From the results it is clear that the ceramic residuals can be used as partial replacement for fine aggregates in concrete without changing the properties of conventional concrete for $15 \%, 20 \%$ for $30 \%$ replacement

Cwirzen A (2010)[17] found the effect of nano-materials on physical properties of cementations materials. The mechanical properties like compressive and flexural strength can be increased up to $50 \%$ by addition of $0.23 \%$ of carbon nano-tubes. Carbon nano-tubes and carbon nano-fibres and/or nano-silica. After addition of carbon nanofibres improves the frost resistance, other properties such as auto genous shrinkage decreased significantly. Nano-silica enabled an immense densification of the hydrated binder matrix, which improves the durability and mechanical properties of the concrete.

Vema Reddy, S.Sridharhave investigated the performance of fresh and hardened properties of concrete containing discarded foundry sand in place of fine aggregate. They have performed the test on the cubes and cylinders having 20\%-100\% replacement of foundry sand. They have concluded that the slump of the concrete decrease with increase in the $\%$ of foundrysand and the compaction factor increases with increase in the $\%$ of foundry sand. The compressive strength of the concrete has increased by $13.42 \%$ by the replacement of $20 \%$ of foundry sand over normal sand. Their results have concluded that up to the $60 \%$ of the replacement of the foundry sand gives rise to the compressive strength of the concrete. The split tensile strength increases up to $60 \%$ replacement of foundry sand after that decrease till $100 \%$.
Pranita Bhandari, Dr. K.M.Tajne, have performed the test to check the compressive strength of concrete at thereplacement of sand by foundry sand. They have conducted the test up to the $100 \%$ replacement of foundry sand. By this experimental work they haveconcluded that the compressive strength of the concrete at the $28 \mathrm{Th}$ daygives maximum strength when the sand is replaced up to $10 \%-20 \%$.

Preeti Pandey, Alvin Harison, Vikas Srivastava, have performed the test to check the fresh and harden properties of concrete with replacement of fine aggregate by foundry sand up to $50 \%$. They have concluded that workability is slightly increases with replacement level. They have concluded that optimum replacement level of foundry sand is $10 \%$ which gives the maximum compressive strength at 28 days.

Khatib and Herkiinvestigated the concrete produced by replacing the fine aggregates with $0 \%, 30 \%, 60 \%$ and $100 \%$ WFS. The water content, coarse aggregate, cement and the water to cement ratio remained constant. The properties investigated at 7,28 and 90 days curing times. The results indicate that there is systematic increase in water absorption by capillary action, a decrease in compressive strength and Ultrasonic pulse velocity with increasing amounts of WFS in concrete. They also reported that adequate strength can be achieved using an appropriate replacement level of foundry sand.

Amitkumar D Raval et al., [1] They carried out an experimental investigation on the topic 'effect of foundry sand as fine aggregate replacement in concrete' with an M25 grade at different limited curing periods (7 days, 14 days and 28 days). Fine aggregate was replaced with $10 \%$, $20 \%, 30 \%, 40 \%$ and $50 \%$ of WFS by weight. The test result showed that the compressive strength increased with an increase in the amount of foundry sand, up to $30 \%$ replacement in concrete, beyond that it decreases.

DushyantRameshbhaiBhimani et al., [3.]They carried out an experimental investigation on the topic "Strength Behavior of Foundry Sand on Modified High Strength Concrete'. Fine aggregate was replaced with $0,15,25$ \& $35 \%$ of WFS by weight in concrete. Compressive strength, split tensile strength and flexural strength tests were carried out to evaluate the strength properties of concrete. Based on their result values they stated that, $25 \%$ replacement give higher strength. They also stated that using of foundry sand for construction work will be more effective and efficient than land filling.

Eknath P. Salokhe et al., [4] They investigated on the topic'Application of Foundry Sand in Manufacture of Concrete'. They have done their experiment in M20 grade concrete. They replaced fine aggregate by foundry sand in 10, $20 \& 30 \%$. They tested the compressive strength and tensile strength of concrete specimen. From their test 
result, they concluded that Split tensile strength is maximum at $20 \%$ replacement. However Ferrous WFS gives slightly more strength than Non-Ferrous WFS. Compressive strength is maximum at $10 \%$ \& $30 \%$ replacement for Ferrous \& Non-Ferrous WFS respectively.

Dr. B. Kameshwari et al., [7] They investigated on the topic 'Strength of concrete incorporating waste foundry sand'. They had done their experiment in Grade M20. They replaced the fine aggregate by foundry sand in 10 , $20,30 \& 40 \%$ by weight in concrete. From their test they concludedthat Maximum compressive strength is obtained at $30 \%$ replacement and then decreases.

Tarun R Naik et al., [10] They investigated on the topic of 'Utilization of Used Foundry Sand in Concrete'. Here they tested the values of the Compressive strength \& Split tensile strength of concrete of M30 grade with the replacements of $25 \& 35 \%$ by weight of fine aggregate at different curing periods of $7 \& 28$ days. They concluded that the compressive strength values having $25 \%$ and $35 \%$ replacement of used foundry sand are lower than the concrete with no replacement. But it shows higher compressive strength when it is replaced by clean/new foundry sand.

\section{MATERIAL USED}

\section{Cement}

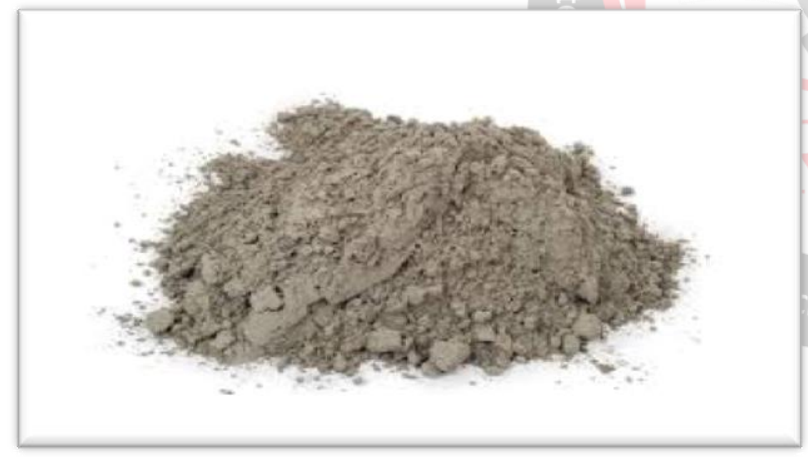

Ordinary Portland cement (OPC) of 53 grade was used. It was tested as per IS specifications.

\section{River sand}

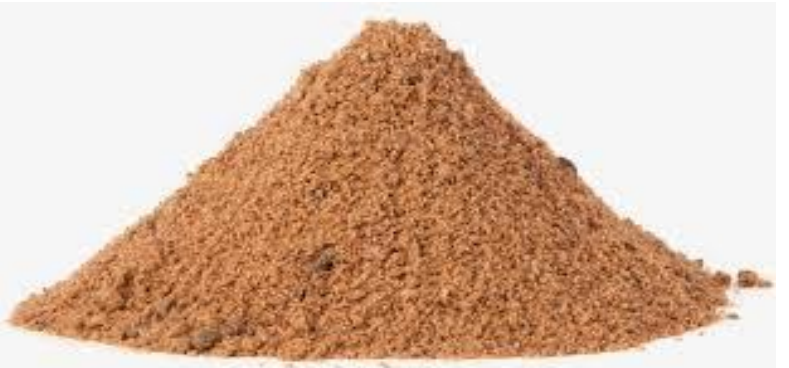

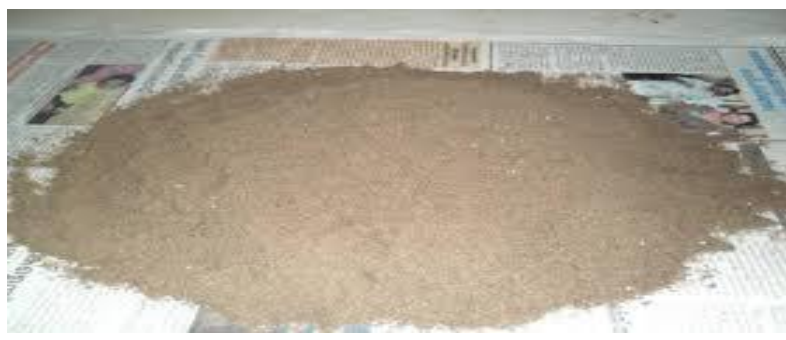

\begin{tabular}{|l|l|}
\hline Physical properties & Test result \\
\hline Specific gravity & 2.5 \\
\hline Water absorption & $4.25 \%$ \\
\hline Grading zone & $\mathrm{I}$ \\
\hline Finess & 2.55 \\
\hline
\end{tabular}

Sand is mainly excavated from river beds. The river sand used as fine aggregate which was passed through $4.75 \mathrm{~mm}$ sieve.

\section{Coarse aggregate}

Angular crushed stone aggregate has been used, with maximum size of aggregate $20 \mathrm{~mm}$.

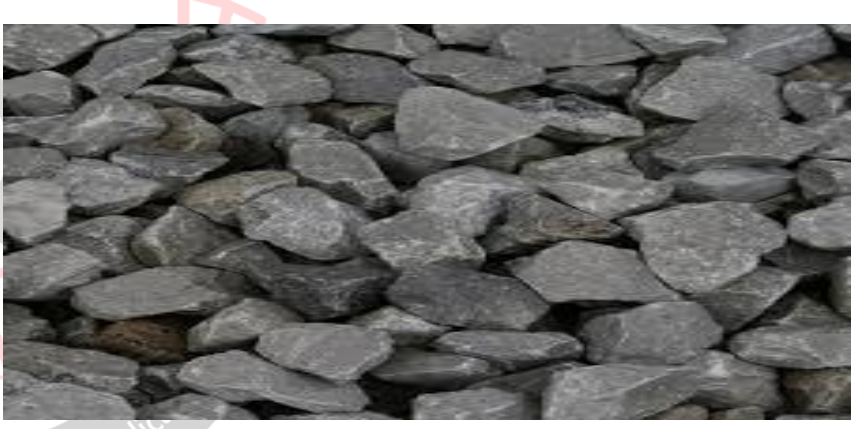

\begin{tabular}{|l|l|}
\hline Physical properties & Average value \\
\hline Specific gravity & 2.8 \\
\hline Water absorption & $0.48 \%$ \\
\hline Types & Crushed \\
\hline Fineness modulus & 5.32 \\
\hline
\end{tabular}

\section{WASTE FOUNDRY SAND}

Waste foundry sand is a by product from foundry industry. In this project foundry sand used as a partial replacement of fine aggregate.

\begin{tabular}{|l|l|}
\hline Physical properties & Test result \\
\hline Normal consistency & $30 \mathrm{~min}$ \\
\hline Initial setting time & $32 \%$ \\
\hline Specific gravity & 3.05 \\
\hline
\end{tabular}




\section{NANO-SILICA}

The nano silica is partially replaced for cement. To increase durability andstrength in cementing operations and groundconsolidation.

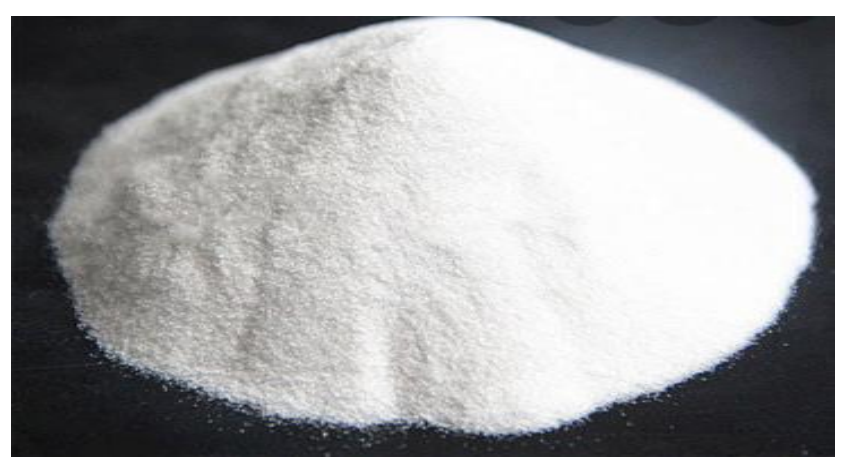

\section{MIX DESIGN}

Table-1: Mix Design

\begin{tabular}{|l|l|}
\hline Title & Specifications \\
\hline Grade of concrete & M25 \\
\hline Type and Grade of cement & OPC (53) \\
\hline Size of coarse aggregate & $20 \mathrm{~mm}$ \\
\hline Specific gravity of cement & 3 \\
\hline Specific gravity of coarse aggregate & 2.08 \\
\hline Specific gravity of fine aggregate & 2.223 \\
\hline W/C Ratio & 0.45 \\
\hline Mix proportion & $1: 1.5: 2.34: 0.44$ \\
\hline
\end{tabular}

\section{EXPERIMENTAL PROCEDURE}

\section{i. Mixing of material}

Different types of batching techniques are available on construction sites. In this project weight batching method is used. The materials are batching in M25 mix proportion ratio.

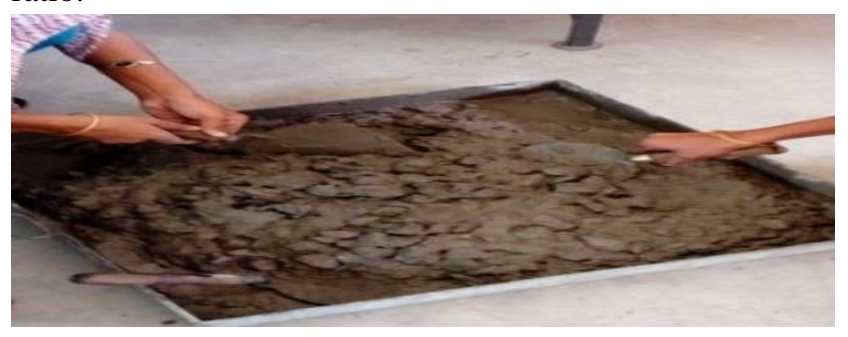

Fig: Mixing of concrete

\section{ii.Casting of specimen}

The concrete cubes were casted in 1:1.5:2.34:0.44 ratio. The cube size of $(150 \times 150 \times 150) \mathrm{mm}$ specimen is prepared for compressive strength.

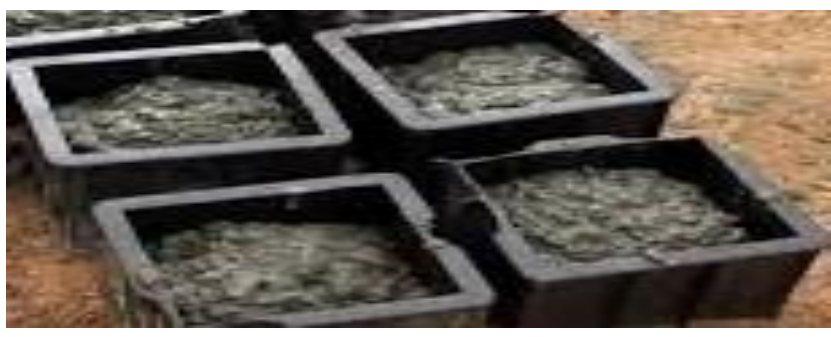

Fig: Moulds filled with Fresh Concrete

\section{iii.Curing of specimen}

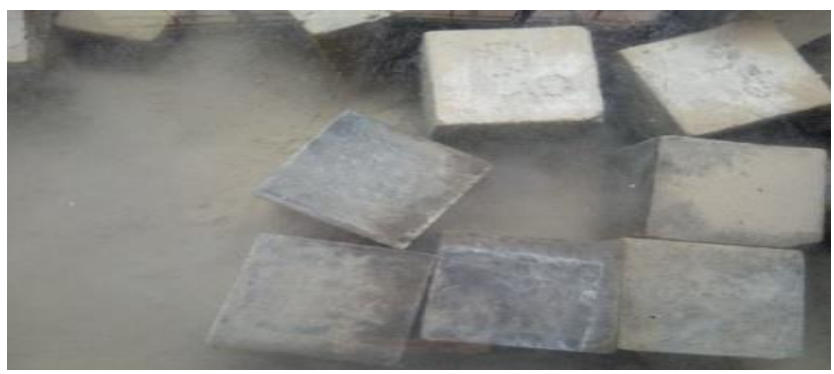

All the test specimens were de-moulded after 24 hours, and were put into a water - curing tank for 28 days at room temperature.

\section{iv. Compressive strength}

Compressive strength at various percentage of replacement of fine aggregate with waste foundry sand. The compressive strength at 7, 14 and 28 days of cured concrete specimen shown in table 2 .

Graph- 1: Compressive strength of result values

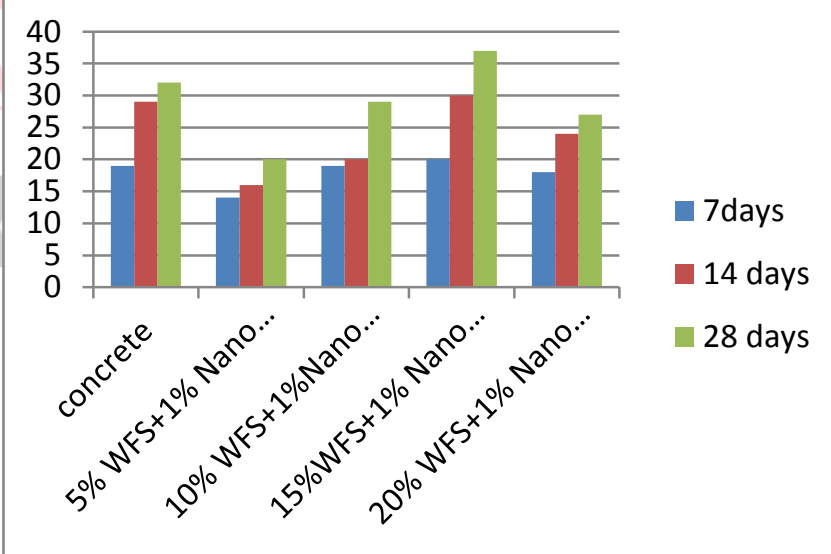

\begin{tabular}{|c|c|c|c|}
\hline Mix & $\begin{array}{c}7 \text { days } \\
\left(\mathrm{N} / \mathrm{mm}^{2}\right)\end{array}$ & $\begin{array}{c}14 \text { days } \\
\left(\mathrm{N} / \mathrm{mm}^{2}\right)\end{array}$ & $\begin{array}{c}28 \text { days } \\
\left(\mathrm{N} / \mathrm{mm}^{2}\right)\end{array}$ \\
\hline $\begin{array}{c}\text { Conventional } \\
\text { concrete }\end{array}$ & 19 & 29 & 32 \\
\hline $\begin{array}{c}5 \% \text { WFS+ } \\
1 \% \text { Nano silica }\end{array}$ & 14 & 16 & 20 \\
\hline $\begin{array}{c}10 \% \text { WFS+ } \\
1 \% \text { Nano silica }\end{array}$ & 19 & 20 & 29 \\
\hline $\begin{array}{c}15 \% \text { WFS+ } \\
1 \% \text { Nano silica }\end{array}$ & 20 & 29 & 34 \\
\hline $\begin{array}{c}20 \% \text { WFS+ } \\
1 \% \text { Nano silica }\end{array}$ & 18 & 24 & 27 \\
\hline
\end{tabular}

Table-2 TEST RESULTS 


\section{CONCLUSION}

Based on the experimental study undertaken the following conclusion.

Waste foundry sand and nanosilica can be effectively used as fine aggregate and cement in concrete.

Replacement of cement with $1 \%$ of nanosilica gives more strength then the waste foundry sand mix and also durability has been increased compared to conventional concrete.

At $15 \%$ waste foundry sand and $1 \%$ nanosilica replacement of sand and cement gives maximum strength at the 28 days.

Thus foundry sand is the good replacement of fine aggregate.

Achieved economy, strength with the use of foundry sand and nanosilica.

\section{REFERENCE}

[1] Amitkumar D. Raval, Alefiya I. Kachwala, "Foundry sand: utilisation as a partial replacement of fine aggregate for establishing sustainable concrete", 2015.

[2] Deepak chaurasiya, P.C Satpute, "Utilisation of foundry sand: An art to replace fine sand with foundry sand", 2016.

[3] Eknath P Salokhe, D. B. Desai"Application of foundry waste sand in manufacture of concrete",IOSR Journal of mechanical and civil engineering (OIOSR- JMCE) ISSN:2278-1684, PP: 43-48.

[4] Gupreet singh, Rafat Siddique, "Abrasion resistance and strength properties of concrete containing waste foundry sand", 2012.

[5] Jayachandra, DG. Narayana, "Strength behaviour of foundry sand on modified higth strength concrete", 2015.

[6] Dr.B. Kmeshwari, M, Vijayan. V, "Strength of concrete incorporating waste foundry sand",2014.

[7] Tarun R. Naik, Mathew P. Tharaniyil, "Utilisation of used foundry sand in concrete", 2015.

[8] Concrete mix proportioning by Francis De Larrard.

[9] Concrete Technology by M.L. Gambhir.

[10] Concrete and construction Handbook by Edward G.

Nawy. 